\title{
Impact of initial phage/host ratio and nutrient addition on coexistence in a phage-host system
}

\author{
Arite Wolf ${ }^{1,2,5}$, TianLing Zheng ${ }^{3,6}$, Karl-Paul Witzel ${ }^{4}$, Günter Jost ${ }^{1, *}$ \\ ${ }^{1}$ Institut für Ostseeforschung Warnemünde, Seestraße 15, 18119 Rostock, Germany \\ ${ }^{2}$ Fachbereich Biologie, Universität Rostock, Ökologie, Freiligrathstraße 7-8, 18051 Rostock, Germany \\ ${ }^{3}$ Environmental Sciences Research Center, Xiamen University, Xiamen, 361005, PR China \\ ${ }^{4}$ Max-Planck-Institut für Limnologie, PO Box 165, 24302 Plön, Germany
}

${ }^{5}$ Present address: Fachbereich Biologie, Mikrobiologie, Universität Rostock, Albert-Einstein-Straße 3, 18059 Rostock, Germany

${ }^{6}$ Present address: School of Life Sciences, Xiamen University, Xiamen, 361005, PR China

\begin{abstract}
The influence of specific phages on the population size of their host bacteria was studied using a model system of a selected phage and its host bacterium, identified as Aeromonas sp. isolated from a lagoon in the southern Baltic Sea. For all initial phage/host ratios (PBR [phage/bacterium ratio] of 0.1 to 100), phage and host abundances reached a ratio of about 5 to 50 within the first $8 \mathrm{~h}$. Interestingly, this range of phage/bacterium ratios of a single phage-host system corresponds to the ratio of virus to bacterial abundance found in natural habitats. The proportion of sensitive cells containing mature phage particles increased in the first $4 \mathrm{~h}$ to $40 \%$, and then decreased (at rates dependent on the initial ratio) within $12 \mathrm{~h}$ (initial PBR of 100), $48 \mathrm{~h}$ (initial PBR of 10 and 1) and $72 \mathrm{~h}$ (initial PBR of 0.1 ) to less than $1 \%$. There was evidence for rapid development of immunity (probably pseudolysogeny), especially at high initial phage concentrations. After $96 \mathrm{~h}$ incubation, carbon, nitrogen and phosphorus were added to improve the nutritional state of the bacteria. Although nutrients were added to all treatments when phage/host ratios were nearly equal, quite different reactions were observed for the bacteria populations with different initial PBRs. Those with low initial PBRs showed the most pronounced increase.
\end{abstract}

KEY WORDS: Phage-host system · Immunity · Lysogeny · Pseudolysogeny $\cdot$ Phage/bacterium ratio • Coexistence

Resale or republication not permitted without written consent of the publisher

\section{INTRODUCTION}

In earlier studies, low phage concentrations measured as plaque-forming units (PFU) (e.g. Moebus 1987) suggested that bacteriophages do not play an important role in microbial food webs. This view was changed when, by transmission electron microscopy, Bergh et al. (1989) detected high concentrations of free viral particles in various aquatic habitats. In most cases these particles exceed bacterial abundances by a factor of 10 or more. These high viral concentrations are thought to be related to substantial mortality of bacterial hosts. Only a small percentage of bacteria carry visible phage particles; nevertheless, a much higher percentage must be considered as irreversibly infected (Proctor et al. 1993). Published values of infected proportions of the bacterial community span a wide range, with a mean value of about $20 \%$ of the heterotrophic bacteria (Suttle 1994). These results indicate lysis of a remarkable fraction of the bacterial community by bacteriophages. Temporarily, viral cell lysis is reported to exceed grazing by nanoflagellates and other bacteriovores (Weinbauer \& Peduzzi 1995) and hence is an important loss factor for the prokaryotic community.

In contrast, high phage concentrations often result in acquisition of resistance (e.g. modification of the phage receptor sites) or immunity (lysogenised cells) by the bacterial host population (Levin \& Lenski 1983). This may reduce the impact of phages on bacterial host populations, or prolong the existence of both populations in the environment. These controversial aspects 
show that no simple relationship can be expected between phages and their hosts, especially not in natural mixed communities, which are subject to further regime factors (e.g. predation, starvation). The mechanisms of the relationship between phages and hosts can be elucidated by studying isolated phagehost systems under conditions closely resembling those in situ.

In this paper we present experimental data on the coexistence of phages and their bacterial host population at various initial phage/host ratios (PBRs). To simulate a bloom situation, phages and bacteria of a model system were added at concentrations comparable to those common in eutrophic habitats. If phages comprise important loss factors at normal in situ abundances, a much higher phage concentration should eliminate or deplete its host population remarkably, although a predator-prey-type oscillation in a phagehost culture might occur. However, the development of resistance or immunity by the bacterial cells should modify the phage/host ratio.

\section{MATERIALS AND METHODS}

Phage-host system. The bacterial host and its phages were isolated from the Zingster Strom, part of a lagoon system in the southern Baltic Sea, where the concentration of bacteria during summer often exceeds $1 \times 10^{7}$ $\mathrm{ml}^{-1}$. The host organism is a gram-negative rod of about $1.6 \times 0.4 \mu \mathrm{m}$ (Fig. 1). Based on results from the API 20NE test system (BioMérieux) and on partial 16S rDNA sequence data (1450 bp), it was identified as

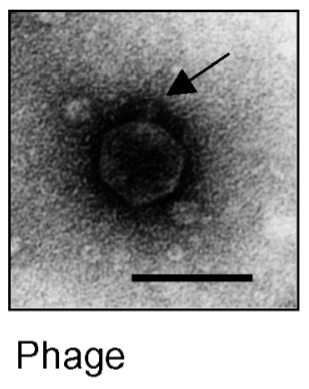

\section{Bacterial host cells}

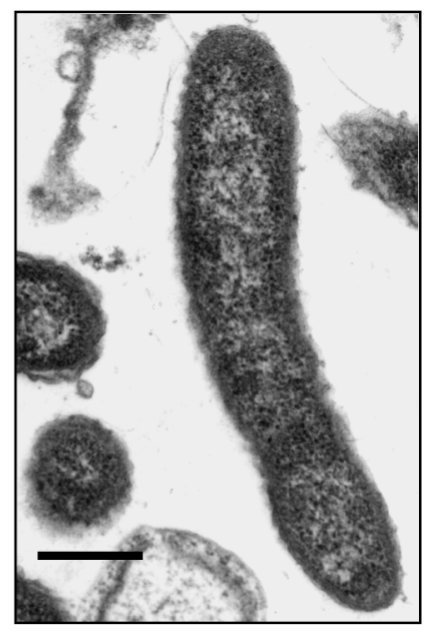

Fig. 1. Electron micrographs of negatively stained phage (family Podoviridae, Morphotype 1; arrow indicates the tail; scale bar $=90 \mathrm{~nm}$ ), and of a thin section of embedded and stained host cells (Aeromonas sp.; scale bar $=0.4 \mu \mathrm{m}$ )
Aeromonas sp., with a similarity of $98 \%$ to $A$. veronii Strain B1 (Accession No. AF099024). The phage belongs to the family Podoviridae (Morphotype 1). It has a hexagonal head with a diameter of about $57 \mathrm{~nm}$ and a short tail of about $12 \mathrm{~nm}$ in length (Fig. 1). The phage produced turbid but clearly visible plaques up to $3 \mathrm{~mm}$ in diameter. The phage latent period was $40 \mathrm{~min}$, with a burst size of 26 phage particles per cell estimated by 1 -step growth curves at $22 \pm 1{ }^{\circ} \mathrm{C}$ in autoclaved habitat water.

Coexistence experiment. Phages and bacteria were incubated in sterile Erlenmeyer flasks at a temperature of $22 \pm 1^{\circ} \mathrm{C}$ and $100 \mathrm{rpm}$ for $10 \mathrm{~d}$ in $250 \mathrm{ml}$ of autoclaved habitat water. Previously, bacteria were cultivated overnight in ZoBell 2216E liquid medium (Oppenheimer \& Zobell 1952) until an optical density (measured as light extinction at $600 \mathrm{~nm}$ ) of 0.4 . We added $5 \mathrm{ml}$ of this bacterial culture to the water sample to a final concentration of about $10^{6} \mathrm{CFU} \mathrm{m} l^{-1}$. Phages were produced by confluent lysis of the host bacteria grown in soft agar plates (Adams 1959) and transferred in $\mathrm{SM}$ buffer $\left(0.1 \mathrm{M} \mathrm{NaCl}, 8 \mathrm{mM} \mathrm{MgSO}_{4} 7 \mathrm{H}_{2} \mathrm{O}, 50 \mathrm{mM}\right.$ Tris- $\mathrm{HCl}, 0.01 \% \mathrm{w} / \mathrm{v}$ glycerine) (Sambrook \& Fritsch 1989) by overlaying $5 \mathrm{ml}$ per plate for $20 \mathrm{~min}$. The phage lysate was sterile-filtered through $0.2 \mu \mathrm{m}$ filter (Millipore). Phages were added to the Erlenmeyer flasks to obtain initial PBRs of 0.1, 1, 10 and 100. In control flasks, bacteria and phages were incubated separately. After $96 \mathrm{~h}$ incubation, carbon (as glucose), nitrogen (as $\mathrm{NaNO}_{3}$ ), and phosphorus (as $\mathrm{K}_{2} \mathrm{HPO}_{4}$ ) were added at Redfield ratios with final concentrations of $300 \mu \mathrm{M} \mathrm{C}, 50 \mu \mathrm{M} \mathrm{N}$ and $3 \mu \mathrm{M}$ P. The added carbon concentration was in the same order of magnitude as the DOC concentration of the original eutrophic environment.

Measurements: phage and host concentrations. After varying time intervals, bacterial cell concentrations were estimated as CFU ml ${ }^{-1}$. Samples from each Erlenmeyer flask were diluted with sterile $0.85 \%(\mathrm{w} / \mathrm{v})$ saline to a dilution of $10^{-6}$ for subsequent cell counting. Plate counts were performed by plating $100 \mu \mathrm{l}$ samples of the last 3 dilutions in duplicate on ZoBell 2216E agar. The plates were incubated at $22 \pm 1^{\circ} \mathrm{C}$ for $48 \mathrm{~h}$ prior to colony counting. The counts from all plates with less than 300 colonies were divided by the sample volume plated to estimate the mean and standard deviation of $\mathrm{CFU} \mathrm{m}{ }^{-1}$. Simultaneously, phage concentrations were estimated as PFU ml ${ }^{-1}$ by the soft agar-layer method (Adams 1959). The samples were diluted with sterile SM buffer (Sambrook \& Fritsch 1989) until dilutions between $10^{-5}$ and $10^{-8}$ were reached. Bacterial cell cultures for the soft agar technique were always grown overnight; $1 \mathrm{ml}$ of the host bacterial culture was mixed with $5 \mathrm{ml}$ of the overlay agar at $45^{\circ} \mathrm{C}$ and poured onto a bottom-agar plate, and $10 \mu \mathrm{l}$ from each of the last 4 
dilutions were dropped onto this soft agar overlay. After an incubation time of $48 \mathrm{~h}$ at $22 \pm 1^{\circ} \mathrm{C}$, the plaques were counted and divided by the sample volume dropped onto the overlay to estimate mean (SD) PFU ml-1.

Host cells containing mature phage particles. On each sampling occasion, $2 \mathrm{ml}$ of each treatment were fixed with sterile filtered glutaraldehyde $(4 \% \mathrm{v} / \mathrm{v}$ final concentration in $0.1 \mathrm{M}$ sodium-phosphate buffer). The cells were washed in buffer and fixed in $\mathrm{OsO}_{4}(1 \% \mathrm{w} / \mathrm{v}$ final concentration). After dehydration in an acetone row from 30 through $100 \%$ acetone $(\mathrm{v} / \mathrm{v})$, the cells were embedded in the epoxy resin 'Araldit' (Fluka) with polymerisation for 2 to $3 \mathrm{~d}$ at $58^{\circ} \mathrm{C}$. Ultrathin sections (50 to $100 \mathrm{~nm}$ ) were post-stained with $2 \%$ aqueous uranyl acetate/lead citrate. Host cells were examined by transmission electron microscopy (Carl Zeiss TEM $902 \mathrm{~A} ; 80 \mathrm{kV}$ ) at a magnification of $20000 \times$. Only cells with more than 3 visible intracellular virus-like particles were considered to be infected cells containing mature phage particles (Proctor \& Fuhrman 1991).

Sensitivity of host cells. After $12 \mathrm{~h}$, about 100 colonies from each treatment were washed from agar plates with $1 \mathrm{ml}$ of liquid Zobell 2216E media, thoroughly mixed and used to prepare an overlay agar. The sensitivity of these host cell populations were tested by dropping the phage fractions $(0.2 \mu \mathrm{m}$ filtrate) onto the soft agar layer. Plates were incubated for $24 \mathrm{~h}$ at $22 \pm 1^{\circ} \mathrm{C}$ until inspection. Visible growth of bacterial cells in the dropping zone was regarded as evidence of a loss of their sensitivity to the phages.

DNA extraction and DNA-DNA hybridisation. Phage DNA within bacteria was detected by DNADNA hybridisation of bacterial DNA from 4 or 5 selected colonies isolated after 72 and $96 \mathrm{~h}$ incubation from each flask with labelled phage probes. Bacterial DNA was isolated by the method of Anderson \& McKay (1983), modified for genomic DNA. Bacterial cells were picked out and dispersed in $2 \mathrm{ml}$ liquid media prior to centrifugation for $5 \mathrm{~min}$ at $14000 \times \mathrm{g}$. The pellet was resuspended in $1 \mathrm{ml}$ STE buffer $(6.7 \% \mathrm{w} / \mathrm{v}$ sucrose, $50 \mathrm{mM}$ Tris, $1 \mathrm{mM}$ EDTA, pH 8) and incubated at $37^{\circ} \mathrm{C}$ for $5 \mathrm{~min}$, and $200 \mu \mathrm{l}$ lysozyme $\left(10 \mathrm{mg} \mathrm{m}^{-1}\right.$ in 25 mM Tris, pH 8) were then added, followed by incubation for a $10 \mathrm{~min}$ with agitation. After adding $120 \mu \mathrm{l}$ Tris-EDTA (50 mM Tris, $0.25 \mathrm{mM}$ EDTA, pH 8) and $70 \mu \mathrm{l}$ of $20 \%(\mathrm{w} / \mathrm{v})$ sodium dodecyl sulfate (SDS) (in $50 \mathrm{mM}$ Tris, $20 \mathrm{mM}$ EDTA, pH 8) the suspension was immediately mixed and vigorously shaken at $37^{\circ} \mathrm{C}$ for another $10 \mathrm{~min}$ until complete lysis. DNA was extracted by adding 1 vol phenol-chloroform $(1: 1, \mathrm{v} / \mathrm{v})$ and centrifuged $\left(5 \mathrm{~min}\right.$ at $\left.4^{\circ} \mathrm{C}, 14000 \times g\right)$. Extant phenol was removed with 1 vol chloroform-isoamyl alcohol $(24: 1, \mathrm{v} / \mathrm{v})$ and additional centrifugation. DNA was precipitated by adding $5 \mathrm{M} \mathrm{NaCl}$ solution (final concentration $0.5 \mathrm{M}$ ) and $1 \mathrm{vol}$ isopropanol at $-20^{\circ} \mathrm{C}$ for at least
$2 \mathrm{~h}$. After an additional washing step using $70 \%(\mathrm{v} / \mathrm{v})$ ethanol, the DNA was resuspended in about $50 \mu \mathrm{l}$ TE buffer (10 mM Tris, $1 \mathrm{mM}$ EDTA) and stored at $-20^{\circ} \mathrm{C}$.

The DNA of phages was isolated by the method of Sambrook \& Fritsch (1989), slightly modified: $1 \mathrm{ml}$ of phage lysate containing at least $10^{6} \mathrm{PFU} \mathrm{ml}{ }^{-1}$ was mixed with $2 \mu \mathrm{l}$ of a mixture of RNase/DNase $(5 \mathrm{mg}$ $\mathrm{ml}^{-1}$ RNase A, $1 \mathrm{mg} \mathrm{ml}^{-1}$ DNase 1 in $50 \%$ glycerol) to remove extracellular nucleic acids. After incubation at $37^{\circ} \mathrm{C}$ for $45 \mathrm{~min} 150 \mu \mathrm{l} 200 \times \mathrm{TE}$ buffer $(2 \mathrm{M}$ Tris, $0.2 \mathrm{M}$ EDTA, pH 7.5) and $30 \mu \mathrm{l} 10 \%$ (w/v) SDS were added. The resulting suspension was agitated thoroughly and incubated at $70^{\circ} \mathrm{C}$ for $10 \mathrm{~min}$. Thereafter, $125 \mu \mathrm{l}$ potassium acetate ( $3 \mathrm{M}$ potassium acetate, $5 \mathrm{M}$ glacial acetic acid) were added. The suspension was placed on ice for $30 \mathrm{~min}$. Proteins were removed by phenolchloroform extraction and centrifugation at $4^{\circ} \mathrm{C}$ and $14000 \times g$ for $15 \mathrm{~min}$, as described for bacterial DNA. DNA was visualised in a $0.8 \%$ agarose gel by ethidiumbromid under UV light and the concentration was estimated spectroscopically.

Labelling of phage DNA and hybridisation with immobilised bacterial genomic DNA was carried out by digoxigenin (DIG) nucleic acid labelling and detection kit (Boehringer Mannheim Biochemica) according to the instructions of the manufacturer. Whole-phage DNA was applied at a final concentration of 50 to $750 \mathrm{ng}^{-1}$ to produce the labelled probe. The hybridisation probe was diluted 1:1000 in hybridisation buffer.

About 1 to $2 \mu \mathrm{g}$ of bacterial DNA and about $0.1 \mu \mathrm{g}$ of phage DNA were transferred onto the hybridisation membrane (Hybond-N, Amersham Pharmacia Biotech). DNA transfer was performed either by Southern blotting after $72 \mathrm{~h}$ incubation or by dot-blotting after $96 \mathrm{~h}$ incubation. For Southern blotting, the DNA was denatured in agarose gel $(0.8 \% \mathrm{w} / \mathrm{v})$ for $30 \mathrm{~min}$ with Solution A (0.5 M NaOH, $1.5 \mathrm{M} \mathrm{NaCl})$ and neutralised

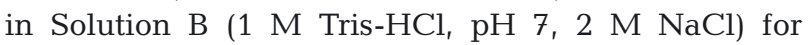
another $30 \mathrm{~min}$. After washing the gel and nylon membrane in $2 \times \mathrm{SSC}(0.3 \mathrm{M} \mathrm{NaCl}, 0.03 \mathrm{M}$ sodium citrate, $\mathrm{pH} 7$ ), a capillar blot was performed overnight. For dotblotting, the DNA was denatured for $15 \mathrm{~min}$ at $98^{\circ} \mathrm{C}$. The membrane was prepared with $10 \times \operatorname{SSC}(1.5 \mathrm{M}$ $\mathrm{NaCl}, 0.15 \mathrm{M}$ sodium citrate, $\mathrm{pH} 7$ ). The DNA was dropped onto the membrane and washed with $2 \times \mathrm{SSC}$ $(0.3 \mathrm{M} \mathrm{NaCl}, 0.03 \mathrm{M}$ sodium citrate, $\mathrm{pH} 7)$ in a blotting chamber. In both cases the membrane was dried and the DNA was fixed by UV light for 3 min. Hybridisation was performed over $18 \mathrm{~h}$ at $68^{\circ} \mathrm{C}$.

Statistical analysis. The significance of differences was calculated by the non-parametric rank-test of Wilcoxon. Differences were considered significant if $\mathrm{p}<0.05$. Correlation between the parameters was determined by a Spearman rank-correlation test (Lozán \& Kausch 1998). 


\section{RESULTS}

\section{Changes in phage and host concentrations}

Temporal changes in phage and host concentrations for the different treatments are shown in Fig. 2. Despite high variability, clear trends could be distinguished over time, and significantly different medians were recorded for different periods and treatments. The concentration of phages without host bacteria decreased slowly during the experiment at a rate of about $1 \% \mathrm{~h}^{-1}$. The host cells showed no response in the absence of phages until the nutrients were added. There- after, the bacterial concentration increased significantly by a factor of about 10, before decreasing slowly from about $180 \mathrm{~h}$ towards the end of the experiment.

At an initial PBR of 0.1 or 1 , the concentration of phages increased rapidly within the first $8 \mathrm{~h}$ to a PBR of about 5 to 10, while the concentration of their hosts did not decrease significantly. At an initial PBR of 10 or 100, the concentrations of phages and hosts did not change significantly until the addition of nutrients. After about $8 \mathrm{~h}$ incubation at all initial PBRs, equilibrium of phage and host cell concentrations was observed. About $7 \times$ (median of PBRs $0.1,1$ and 10, omitting the first 2 values from PBRs 0.1 and 1 ) to $34 \times$
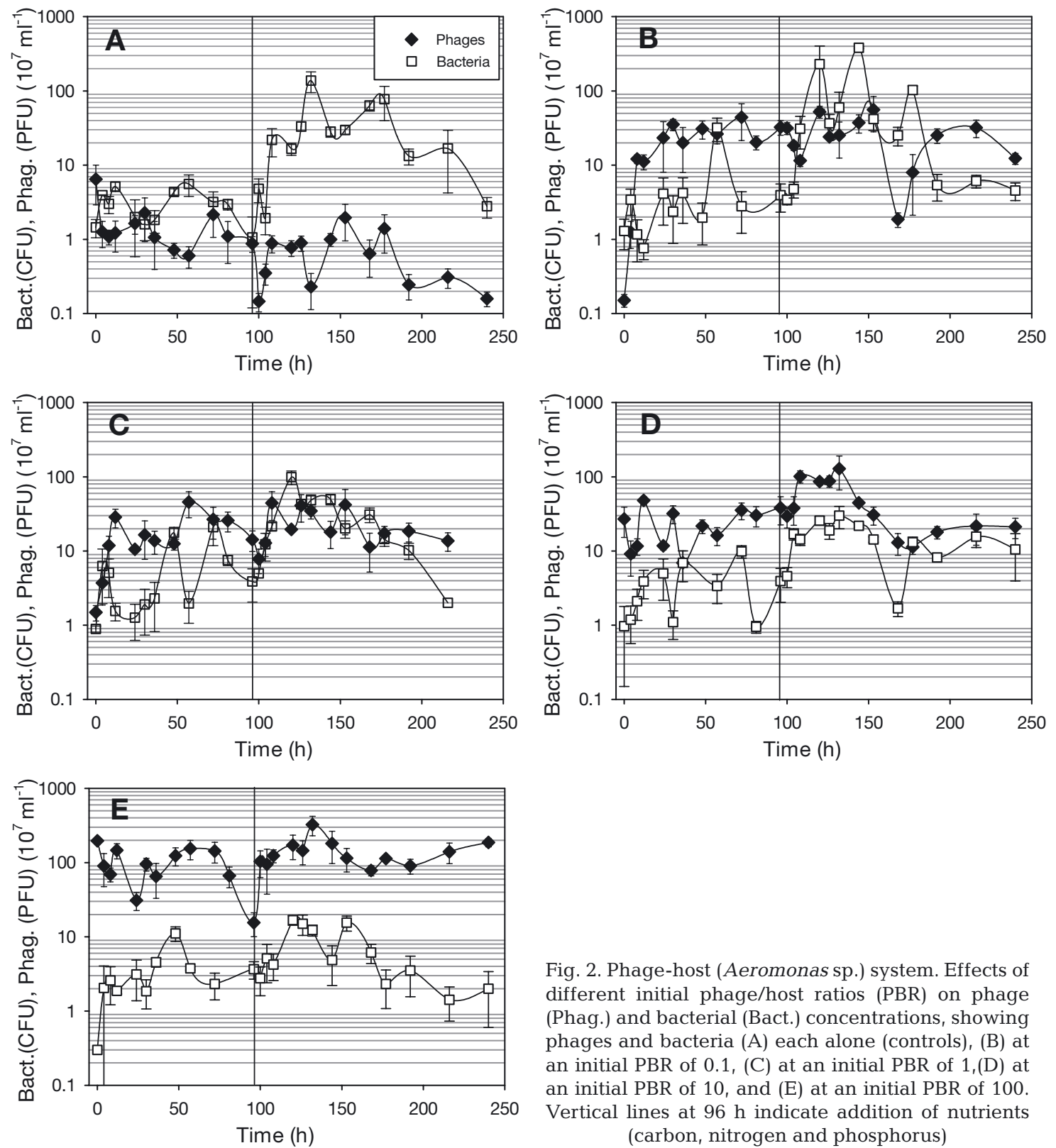

Fig. 2. Phage-host (Aeromonas sp.) system. Effects of different initial phage/host ratios (PBR) on phage (Phag.) and bacterial (Bact.) concentrations, showing phages and bacteria (A) each alone (controls), (B) at an initial PBR of $0.1,(\mathrm{C})$ at an initial PBR of 1,(D) at an initial PBR of 10, and (E) at an initial PBR of 100. Vertical lines at $96 \mathrm{~h}$ indicate addition of nutrients (carbon, nitrogen and phosphorus) 
(median of PBR 100) more phages than bacteria were detected (Fig. 3). The median PBR of the treatment with the highest initial PBR persisted at a significant higher level than all other treatments, which did not differ significantly from each other.

After addition of nutrients, the bacterial concentrations increased to different levels. The highest bacterial concentration was reached at an initial PBR of 0.1 , where the phage concentration at the beginning had been lowest. The host cell concentration at the highest initial PBR of 100 showed the lowest increase. The addition of nutrients and the response of the host populations had smaller effects on the phage concentrations than on host abundances. This resulted in a shift of the PBRs to a lower level (Fig. 3): the lower the initial PBR, the faster the shift. Compared to ratios prior to nutrient addition, the median phage/host ratios for the populations with initial PBRs of 0.1 and 1 decreased significantly to about 1 , with no significant difference between them. In the treatments with higher initial PBRs of 10 and 100, median PBR decreased also, but the declines after addition of nutrients were insignificant. Predator-prey-type oscillations between phage and host concentrations was not observed.

Bacterial concentrations had decreased by the end of the experiment in all treatments. The decline seemed to start between 180 and $200 \mathrm{~h}$, and was also observed in the control with bacteria alone. This and the few visible infected cells in the treatments with phages at this time indicate a nutrient-dependent rather than a phage-induced decrease in the host population.

\section{Frequency of cells containing mature phage particles}

The proportion of cells containing mature phages (Fig. 4) increased during the first $4 \mathrm{~h}$ incubation to $40 \%$
Fig. 4. Phage-host (Aeromonas sp.) system. Electron micrograph of thin section of host cells containing mature phage particles (scale bar $=$ $0.4 \mu \mathrm{m})$

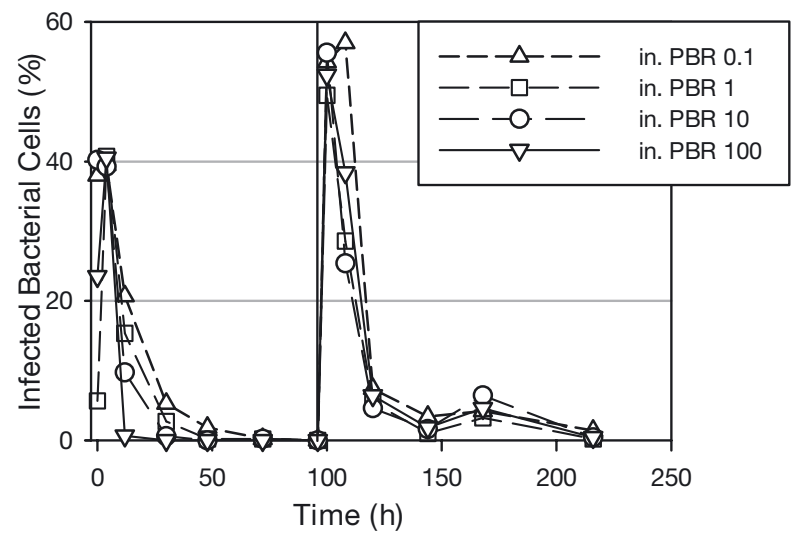

Fig. 5. Phage-host (Aeromonas sp.) system. Changes in percentage of host cells containing mature phage particles at different initial phage/host ratios (in. PBR). Vertical line at $96 \mathrm{~h}$ indicates addition of nutrients (carbon, nitrogen and phosphorus)
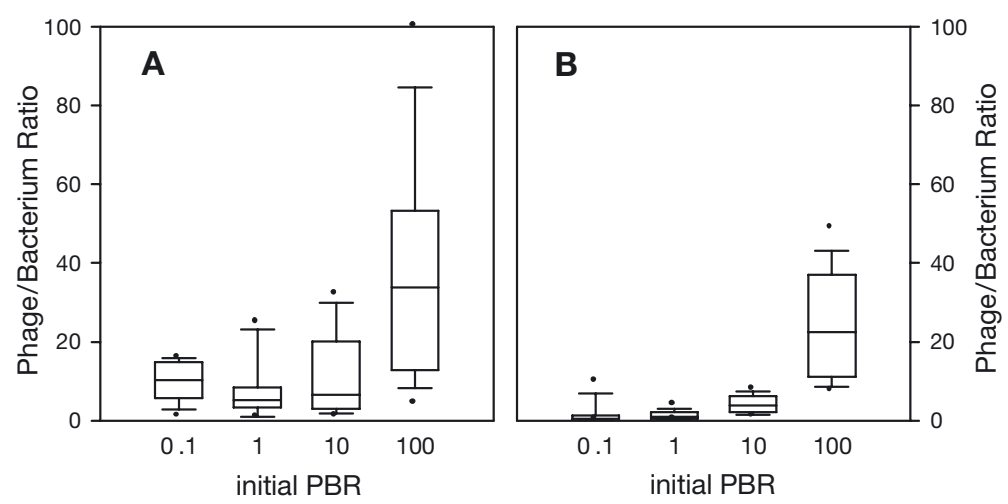

Fig. 3. Phage-host (Aeromonas sp.) system. Box-whisker plots of phage/host ratios for different initial phage/host ratios (A) before (time interval 0 to $96 \mathrm{~h}$ ) and (B) after addition of nutrients (time interval 100 to $177 \mathrm{~h}$ ) at all initial PBRs and decreased rapidly afterwards (Fig. 5), with the decrease (to less than $1 \%$ ) varying as a function of initial PBR: within $12 \mathrm{~h}$ at PBR 100, $48 \mathrm{~h}$ at PBRs 10 and 1 and $72 \mathrm{~h}$ at PBR 0.1. After nutrient addition, the proportion of infected cells increased again to $57 \%$ (mean value of all initial PBRs) and subsequently decreased rapidly within the following $24 \mathrm{~h}$ to less than $5 \%$, with no significant differences among treatments.

\section{Sensitivity of host cell populations}

After $12 \mathrm{~h}$ incubation, a loss of phage sensitivity of those bacterial populations that had co- 

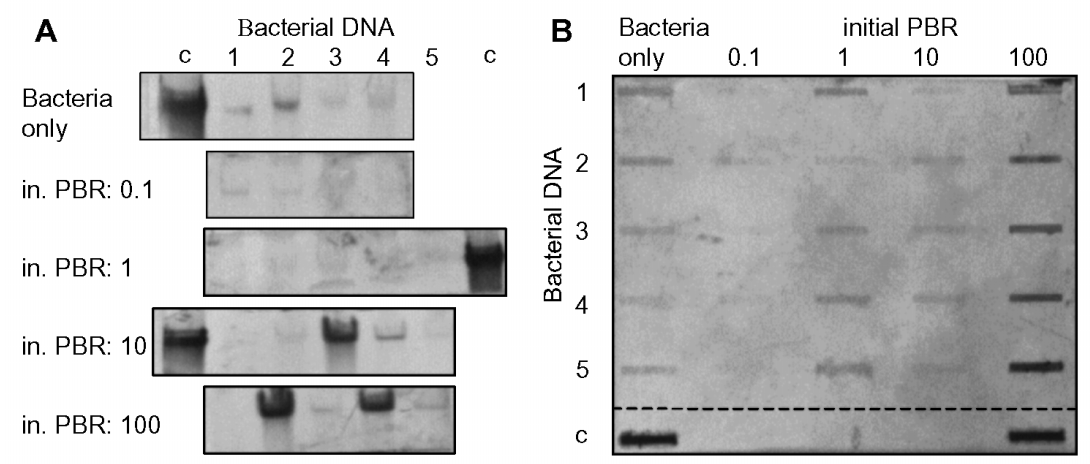

Fig. 6. Phage-host (Aeromonas sp.) system. Evidence for cells containing phage DNA by (A) Southern-blot hybridisation after $72 \mathrm{~h}$, and (B) dot-blot-hybridisation after 96 h. 1-5: hybridisation of bacterial DNA; c: control (hybridisation of the phage DNA)

existed in contact with phages was observed. In soft agar layer these bacteria showed no lysis in the dropping zones of the phage fractions in any flask, in contrast to those bacteria that had been grown without contact to phages. The latter showed clear lysis zones in the dropping regions of all phage fractions.

\section{Detection of phage DNA within bacteria}

After 72 and $96 \mathrm{~h}$ incubation, evidence of prophages within bacterial cells was demonstrated by hybridisation of immobilised bacterial DNA with a specific phage probe (Fig. 6). After $72 \mathrm{~h}$ at high initial phage concentrations (PBRs 10 and 100), a positive reaction could be detected in 1 and 2 out of 5 tested bacterial isolates, respectively. After 96 h, a signal was obtained for all 5 tested colonies of the flask with an initial PBR of 100 . The control reaction with phage DNA led to stronger hybridisation signals in all cases.

\section{DISCUSSION}

Lysis by phages is a major factor controlling mortality in bacterial communities (Proctor et al. 1993, Suttle 1994, Hennes \& Simon 1995, Weinbauer \& Peduzzi 1995, Weinbauer \& Höfle 1998). Peaks of bacterial abundance are followed by an increase in viral concentrations and collapse of bacterial blooms (Bratbak et al. 1990, Boehme et al. 1993, Weinbauer et al. 1993, Jiang \& Paul 1994). Hence we assumed a significant, but sporadic, impact of phages on their host populations.

Considerable fluctuations in the estimated concentrations of phages and bacteria that could arise from different sources (e.g. aggregation or adsorption of phages or bacteria, different dryness of plates) did not affect the general conclusions we drew based on trends observed in several treatments, or nonparametric comparison of medians for particular time periods. Although we incubated the phages and their host bacteria together at various initial PBRs, after $8 \mathrm{~h}, 5$ to 10 times more phages than bacterial cells were present in all treatments. Similar ratios have been detected in natural habitats for mixed bacterial populations and their phages (Bergh et al. 1989, Wommack et al. 1992, Paul et al. 1993). Also, during a theoretical study of the relationship between bacterial populations (10 dominant populations) and their lytic phages in aquatic systems, Thingstad (2000) calculated a PBR of about 12 as equilibrium value. In our experiments, phage concentration increased rapidly over time at low initial PBRs. Middelboe et al. (2001) showed a similar strong increase in phage concentrations during batch cultures of 4 different aquatic phage-host systems: corresponding to an increase in phage concentrations, all 4 bacterial concentrations decreased by several orders of magnitude within the first $15 \mathrm{~h}$. We did not see such a strong decrease in bacterial concentration in any of our treatments. Only at the 2 lower initial PBRs was an insignificant decrease (if any) in bacterial concentration observed, but it soon recovered to the initial concentration. Adding phages at PBRs higher than 10 seemed to have no significant effect on either phage or host concentration. This appears to reflect a dynamic equilibrium rather than a state without interactions between phages and hosts. The ratio of 5 to 50 times more phages than bacteria was stable until the addition of nutrients. Consequently, the host population did not collapse through phage lysis.

The proportion of cells containing mature phages was estimated to be as much as $40 \%$ after only $4 \mathrm{~h}$ incubation at all initial PBRs. Mature phages inside cells are usually only visible for a short time during their development. Therefore, the proportion of actually infected cells would be much higher. The mortality rate of the bacterial population caused by phage lysis was postulated to be twice as high as the infection rate by Proctor et al. (1993), whose model assumes that at an infection rate of $50 \%$ and a mortality of $100 \%$ bacterial abundance remains constant and the 'new' production is removed. Thus our observed infection frequency of $40 \%$ corresponding to $80 \%$ mortality, would still allow the observed growth of the population. At the beginning of the experiment, however, we 
assumed that all host cells were infected simultaneously when phages were added, so that the proportion of actually infected cells should be identical with the proportion of visible infected cells. This frequency of visible infection of $40 \%$ of the bacterial cells could therefore represent the true infection level. These infection and mortality rates did not reduce the host population significantly. A defence response of the host bacteria soon after contact between phage and host cell may be the reason. Subsequently, the fraction of visibly infected cells decreased below the detection limit. Although after $4 \mathrm{~h}$ the observed phage/host proportions were nearly equal, irrespective of initial PBR, the decrease was more rapid at high initial PBRs than at low ones. Therefore, the higher the phage concentration, the faster the hosts seem to respond with a defence mechanism.

For all bacterial populations with phage contact, a loss of sensitivity was observed after $12 \mathrm{~h}$ incubation, while bacteria without contact with phages preserved their sensitivity. Because of the promptness of the response, resistance in the sense of a genetic mutation should be excluded (Lenski \& Levin 1985). We would rather suppose a phage-driven change in the host cell surface and phage receptors.

By hybridisation of bacterial DNA, prophages could be detected inside the cells. We could not provide true evidence for lysogenisation of phage DNA into host chromosomal DNA. Therefore, the co-isolation of phage DNA from bacterial cells may indicate a state of immunity, probably caused by pseudolysogeny rather than true lysogeny. Pseudolysogeny defines a condition in which the host cells coexist with their phage genome in an unstable relationship (Baess 1971). Mostly it occurs in starved bacterial cells. As nutrients are supplied, pseudolysogeny resolves into either true lysogeny or lytic production of viral particles (Ripp \& Miller 1998). Ackermann \& Dubow (1987) described pseudolysogeny as phenomenon whereby a constant production of phages in the presence of high host cell abundance occurred; phage lysis does not result in a drastic decline in the host population, but in a state in which a high phage abundance coincides with exponential host growth. Because of the similarity of our findings, we assume pseudolysogeny rather than true lysogeny. The detection of prophages only at high initial phage concentrations may point to a phage concentration-dependent defence response.

After addition of nutrients, bacterial concentration increased as a function of initial phage concentration. Despite the same equilibrium among all initial PBRs (with the exception of PRB 100) at the time of nutrient addition, the abundance of bacterial cells increased more at low initial PBRs (Table 1). This was comparable to the reaction of bacteria in the control culture without contact with phage particles; at higher initial PBRs smaller changes occurred. This could be attributable to higher cell lysis, as indicated by an increase in the phage concentrations. Accordingly, we assume that prophages were induced by a higher cellular nutrient turnover (Moebus 1997C, Ripp \& Miller 1997, 1998). The addition of phosphorus might be the trigger (Tuomi et al. 1995, Wilson \& Mann 1997). This fast induction is another hint of pseudolysogeny (Baess 1971, Ripp \& Miller 1997).

However, the distinction between lysogeny and pseudolysogeny seems less important than the acquirement of immunity and return to the lytic cycle. In most studies, relatively strong inducing agents like mitomycin C or UV radiation have been used to induce the lytic cycle in lysogenic bacteria in aquatic environments (e.g. Jiang \& Paul 1994, 1998, Weinbauer \& Suttle 1996, Tapper \& Hicks 1998). In a host culture, Jiang et al. (1998) found phage DNA integrated in the host chromosome as well as in the plasmid fraction. Also, a high frequency of spontaneous induction to lytic replication was detected in host cultures. Since the prophage causes homoimmunity by preventing lytic replication of the same phage but not injection of phage DNA, this may explain the occurrence of phage DNA in the plasmid fraction. In this case, only spontaneous induction of the prophage is sufficient to produce free phage particles as well as introducing its DNA into most of the bacterial cells. Further investigation of this phage-host system led to the conclusion that, either by weak repression of phage synthesis or by a change of the cell surface resulting in very poor phage adsorption, a lysogenic relationship was achieved that resembles pseudolysogeny (Williamson et al. 2001).

Table 1. Median concentrations of bacteria and phages before (time interval 0 to $96 \mathrm{~h}$ ) and after (time interval 100 to $177 \mathrm{~h}$ ) addition of nutrients in bacterial control and in treatments with different initial phage/host ratios (PBRs). PFU: plaque-forming units

\begin{tabular}{|c|c|c|c|c|c|c|}
\hline \multirow{2}{*}{ Parameter } & \multirow{2}{*}{$\begin{array}{c}\text { Time interval } \\
\text { (h) }\end{array}$} & \multirow{2}{*}{ Control } & \multicolumn{4}{|c|}{ Initial PBR } \\
\hline & & & 0.1 & 1 & 10 & 100 \\
\hline \multirow{2}{*}{$\begin{array}{l}\text { Bacterial concentration } \\
\left(\text { median, } 10^{6} \mathrm{CFU} \mathrm{ml}^{-1} \text { ) }\right.\end{array}$} & $0-96$ & 3 & 3 & 2 & 3 & 3 \\
\hline & $100-177$ & 29 & 39 & 26 & 16 & 6 \\
\hline \multirow{2}{*}{$\begin{array}{l}\text { Phage concentration } \\
\left(\text { median, } 10^{6} \mathrm{PFU} \mathrm{ml} \mathrm{m}^{-1}\right)\end{array}$} & $0-96$ & 1 & $25^{\mathrm{a}}$ & $17^{\mathrm{a}}$ & 24 & 93 \\
\hline & $100-177$ & 1 & 25 & 19 & 41 & 119 \\
\hline \multicolumn{7}{|c|}{${ }^{\mathrm{a} O n l y ~ d a t a ~ f r o m ~} 8$ to $96 \mathrm{~h}$ used } \\
\hline
\end{tabular}


The observed increase in the proportion of visibly infected cells after the addition of nutrients could be due to prophage induction. The loss of sensitivity in all treatments containing phages as well as the increasing detection rate of phage DNA within host DNA with increasing initial PBR suggest that at least a partial induction of prophages is responsible for the observed slight increase in phage concentrations and the even lower increase in bacterial concentrations in the treatments with initial PBRs of 100 and 10 compared to the other treatments. Rather unclear is the increase in the fraction of visibly infected cells to about the same value at all initial PBRs. A possible explanation could be that after adding nutrients in all cases, still existing sensitive cells increased substantially before they were infected, and these were responsible for the increased fraction of bacteria with mature phage particles, especially at low initial PBRs. In these treatments new insensitive cells seemed to be responsible for the observed strong increase in bacterial concentrations, whereas in the treatments with initial PBRs of 10 and 100 the amount of visibly infected cells may have been caused mainly by induction of prophages, which ties up with the dominance of immune cells. Therefore, the 2 processes - infection of sensitive cells and induction of prophages - might result in similar percentages of infected cells, although they might affect a population to different extents, depending on the history of the cultures.

The lysogenic strategy ensures the survival of their phages during suboptimal conditions of its host cells, e.g. nutritional starvation (Levin \& Lenski 1983, Ripp \& Miller 1997, 1998). Obviously, not only limited nutrient conditions (Ripp \& Miller 1997, 1998), but also high phage concentrations can lead to lysogeny. The development of immunity by either lysogeny or pseudolysogeny and the adjustment of an equilibrium between the concentrations of phages and their bacterial hosts seems to be a common phenomenon in natural environments (Lenski \& Levin 1985, Ogunseitan et al. 1990, Moebus $1997 \mathrm{a}, \mathrm{b}, \mathrm{c})$. This is reflected by the high proportion of lysogenic or pseudolysogenic bacteria found within bacteria from various environments (Ogunseitan et al. 1992, Jiang \& Paul 1998). Immunity might also contribute to the discrepancy between high concentrations of virus-like particles and the difficulty in isolating host strains. Reported efficiencies are within 5 to $45 \%$ (mean of about 10 to $15 \%$ ) of isolates from aquatic samples in which phages could be detected (Hidaka 1973, Willoughby 1976, Moebus 1980, Alonso et al. 2002).

Besides the widely discussed importance of lysogeny and pseudolysogeny for the coexistence of phages and their hosts, we should not forget the establishment of resistance within the host population. The existence of this mechanism was supported by the successful continuous culture of different phage-host systems isolated from a marine ecosystem by Middelboe (2000) and Middelboe et al. (2001). A decrease during the development of CFUs caused by a strong decrease in sensitive cells due to lysis and an increase in resistant cells from a low level should be an indication of this mechanism.

This study is based on only a single, isolated, phagehost system from a natural aquatic environment carried out to assess different strategies of coexistence of phages and their hosts. At the moment we are far from understanding the coexistence of a mixture of different bacterial species and their phages in natural aquatic ecosystems. Information from well investigated phage-host systems has improved our knowledge of mechanisms of coexistence. However, considering the huge diversity of bacteria, more studies of phage-host systems are necessary to elucidate the mechanisms of coexistence between phages and their specific host populations in more detail and their fluctuation under the variable conditions of their natural habitats.

Acknowledgements. We thank the collaborators of the Centre of Electron Microscopy of the University of Rostock for their help and the use of their equipment. We also thank Sabine Bauer for helpful suggestions to improve an early draft, and anonymous reviewers for valuable comments on the manuscript. This work was supported by a scholarship to A. Wolf from the Deutsche Forschungsgemeinschaft (DFG) within the Graduiertenkolleg 'Integrative analysis of tideless coast habitats' at the University of Rostock. T.L.Z.'s stay at the I.O.W. was supported by a short-term research grant of the DFG.

\section{LITERATURE CITED}

Ackermann HW, Dubow MS (1987) Viruses of prokaryotes, Vol 1. General properties of bacteriophages, CRC Press, Boca Raton, FL

Adams MH (1959) Bacteriophages. Interscience Publishers, New York

Alonso MDC, Rodriguez J, Borrego JJ (2002) Characterization of marine bacteriophages isolated from the Alboran Sea (Western Mediterranean). J Plankton Res 24:1079-1088

Anderson DG, McKay LL (1983) Simple and rapid method for isolating large plasmid DNA from lactic streptococci. Appl Environ Microbiol 46:549-552

Baess I (1971) Report on pseudolysogenic mycobacterium and a review of the literature concerning pseudolysogeny. Acta Pathol Microbiol Scand 79:428-434

Bergh Ø, Børsheim KY, Bratbak G, Heldal M (1989) High abundance of viruses found in aquatic environments. Nature 340:467-468

Boehme J, Frischer ME, Jiang SC, Kellogg CA, Pichard S, Rose JB, Steinway C, Paul JH (1993) Viruses, bacterioplankton, and phytoplankton in the southeastern Gulf of Mexico: distribution and contribution to oceanic DNA pools. Mar Ecol Prog Ser 97:1-10

Bratbak G, Heldal M, Norland S, Thingstad TF (1990) Viruses 
as partners in spring bloom microbial trophodynamics. Appl Environ Microbiol 56:1400-1405

Hennes K, Simon M (1995) Significance of bacteriophages for controlling bacterioplankton growth in a mesotrophic lake. Appl Environ Microbiol 61:333-340

Hidaka T (1973) Characterization of marine bacteriophages newly isolated. Mem Fac Fish Kagoshima Univ 22:47-61

Jiang SC, Paul JH (1994) Seasonal and diel abundance of viruses and occurrence of lysogeny/bacteriocinogeny in the marine environment. Mar Ecol Prog Ser 104:163-172

Jiang SC, Paul JH (1998) Significance of lysogeny in the marine environment: studies with isolates and a model of lysogenic phage production. Microb Ecol 35:235-243

Jiang SC, Kellogg CA, Paul JH (1998) Characterization of marine temperate phage-host systems isolated from Mamala Bay, Oahu, Hawaii. Appl Environ Microbiol 64: 535-542

Lenski RE, Levin BR (1985) Constraints on the coevolution of bacteria and virulent phages: a model, some experiments, and prediction for natural communities. Am Nat 125: 585-602

Levin BR, Lenski RE (1983) Coevolution in bacteria and their viruses and plasmids. In: Futuyma DJ, Slatkin M (eds) Coevolution. Sinauer Associates, Sunderland, MA, p 99-127

Lozán JL, Kausch H (1998) Angewandte Statistik für Naturwissenschaftler, Parey Buchverlag, Berlin

Middelboe M (2000) Bacterial growth rate and marine virushost dynamics. Microb Ecol 40:114-124

Middelboe M, Hagström ^̊, Blackburn N, Sinn B and 5 others (2001) Effects of bacteriophages on the population dynamics of 4 strains of pelagic marine bacteria. Microb Ecol 42: 395-406

Moebus K (1980) A method for the detection of bacteriophages from ocean water. Helgol Meeresunters 34:1-14

Moebus K (1987) Ecology of marine bacteriophages. In: Goyal SM, Gerba CP, Bitton G (eds) Phage ecology. Wiley, New York, p 137-156

Moebus K (1997a) Investigations of the marine lysogenic bacterium H24. 1. General description of the phage-host system. Mar Ecol Prog Ser 148:217-228

Moebus K (1997b) Investigations of the marine lysogenic bacterium H24. 2. Development of pseudolysogeny in nutrient-rich broth culture. Mar Ecol Prog Ser 148: $229-240$

Moebus K (1997c) Investigations of the marine lysogenic bacterium H24. III. Growth of bacteria and production of phage under nutrient-limited conditions. Mar Ecol Prog Ser 148:241-250

Ogunseitan OA, Sayler GS, Miller RV (1990) Dynamic interactions of Pseudomonas aeruginosa and bacteriophages in lake water. Microb Ecol 19:171-185

Ogunseitan OA, Sayler GS, Miller RV (1992) Application of DNA probes to analysis of bacteriophage distribution patterns in the environment. Appl Environ Microbiol 58: 2046-2052

Oppenheimer OA, Zobell CE (1952) The growth and viability of sixty-three species of marine bacteria as influence by hydrostatic pressure. J Mar Res 5:115-118

Editorial responsibility: Karin Lochte, Kiel, Germany
Paul JH, Rose JB, Jiang SC, Kellogg CA, Dickson L (1993) Distribution of viral abundance in the reef environment of Key Largo, Florida. Appl Environ Microbiol 59:718-724

Proctor LM, Fuhrman JA (1991) Roles of viral infection in organic particle flux. Mar Ecol Prog Ser 69:133-142

Proctor LM, Okubo A, Fuhrman JA (1993) Calibrating estimates of phage-induced mortality in marine bacteria: ultrastructural studies of marine bacteriophage development from one-step growth experiments. Microb Ecol 25: 161-182

Ripp S, Miller RV (1997) The role of pseudolysogeny in bacteriophage-host interactions in a natural freshwater environment. Microbiology 143:2065-2070

Ripp S, Miller RV (1998) Dynamics of the pseudolysogenic response in slowly growing cells of Pseudomonas aeruginosa. Microbiology 144:2225-2232

Sambrook J, Fritsch EF (1989) Molecular cloning: a laboratory manual, Cold Spring Harbor Laboratory, Cold Spring Harbor, NY

Suttle CA (1994) The significance of viruses to mortality in aquatic microbial communities. Microb Ecol 28:237-243

Tapper MA, Hicks RE (1998) Temperate viruses and lysogeny in Lake Superior bacterioplankton. Limnol Oceanogr 43: 95-103

Thingstad TF (2000) Elements of a theory for the mechanisms controlling abundance, diversity, and biogeochemical role of lytic bacterial viruses in aquatic systems. Limnol Oceanogr 45:1320-1328

Tuomi P, Fagerbakke KM, Bratbak G, Heldal M (1995) Nutritional enrichment of a microbial community - the effects on activity, elemental composition, community structure and virus production. FEMS Microbiol Ecol 16:123-134

Weinbauer MG, Höfle MG (1998) Significance of viral lysis and flagellate grazing as factors controlling bacterioplankton production in a eutrophic lake. Appl Environ Microbiol 64:431-438

Weinbauer MG, Peduzzi P (1995) Significance of viruses versus heterotrophic nanoflagellates for controlling bacterial abundance in the northern Adriatic sea. J Plankton Res 17:1851-1856

Weinbauer MG, Suttle CA (1996) Potential significance of lysogeny to bacteriophage production and bacterial mortality in coastal waters of the Gulf of Mexico. Appl Environ Microbiol 62:4374-4380

Weinbauer MG, Fuks D, Peduzzi P (1993) Distribution of viruses and dissolved DNA along a coastal trophic gradient in the northern Adriatic Sea. Appl Environ Microbiol 59:4074-4082

Williamson SJ, McLaughlin MR, Paul JH (2001) Interaction of the $\Phi H S I C$ virus with its host: lysogeny or pseudolysogeny? Appl Environ Microbiol 67:1682-1688

Willoughby LG (1976) The activity of Streptomyces phagevirus in fresh water. Hydrobiologia 49:215-228

Wilson WH, Mann NH (1997) Lysogenic and lytic viral production in marine microbial communities. Aquat Microb Ecol 13:95-100

Wommack KE, Hill RT, Kessel M, Russek-Cohen E, Colwell RR (1992) Distribution of viruses in the Chesapeake Bay. Appl Environ Microbiol 58:2965-2970

Submitted: March 19, 2002; Accepted: December 12, 2003

Proofs received from author(s): March 29, 2004 